\title{
Amplicon-plus Targeting Technology (APTT) for rapid production of a highly unstable vaccine protein in tobacco plants
}

Kasi Azhakanandam · Sandra M. Weissinger •

Jennifer S. Nicholson · Rongda Qu • Arthur K. Weissinger

Published online: 24 April 2007

(C) Springer Science+Business Media B.V. 2007

Erratum to: Plant Mol Biol (2007) 63: 393-404

DOI 10.1007/s11103-006-9096-9

Due to an unfortunate misunderstanding, the co-corresponding author and the electronic supplementary materials were not properly identified in the original publication. The correct representation of the authors and their affiliations is listed below.

The online version of the original article can be found at http:// dx.doi.org/10.1007/s11103-006-9096-9

Electronic supplementary material The online version of this erratum (doi:10.1007/s11103-007-9168-5) contains the original supplementary material, which is available to authorized users.

K. Azhakanandam · S. M. Weissinger · J. S. Nicholson ·

R. Qu $(\bowtie) \cdot$ A. K. Weissinger $(\bowtie)$

Department of Crop Science, North Carolina State University,

Raleigh 27695, USA

e-mail: rongda_qu@ncsu.edu

S. M. Weissinger

e-mail: arthur@ncsu.edu 